\title{
Pharmaceutical care education in Kuwait: pharmacy students' perspectives
}

Maram G. KATOUE, Abdelmoneim I. AWAD, Terry L. SCHWINGHAMMER, Samuel B. KOMBIAN.

\author{
Received (first version): 8-Jan-2014 Accepted: 2-Aug-2014
}

\begin{abstract}
*
Background: Pharmaceutical care is defined as the responsible provision of medication therapy to achieve definite outcomes that improve patients' quality of life. Pharmacy education should equip students with the knowledge, skills, and attitudes they need to practise pharmaceutical care competently.

Objective: To investigate pharmacy students' attitudes towards pharmaceutical care, perceptions of their preparedness to perform pharmaceutical care competencies, opinions about the importance of the various pharmaceutical care activities, and the barriers to its implementation in Kuwait.

Methods: A descriptive, cross-sectional survey of pharmacy students $(n=126)$ was conducted at Faculty of Pharmacy, Kuwait University. Data were collected via a pre-tested self-administered questionnaire. Descriptive statistics including percentages, medians and means Likert scale rating (SD) were calculated and compared using SPSS, version 19. Statistical significance was accepted at a $p$ value of 0.05 or lower.

Results: The response rate was $99.2 \%$. Pharmacy students expressed overall positive attitudes towards pharmaceutical care. They felt prepared to implement the various aspects of pharmaceutical care, with the least preparedness in the administrative/management aspects. Perceived pharmaceutical care competencies grew as students progressed through the curriculum. The students also appreciated the importance of the various pharmaceutical care competencies. They agreed/strongly agreed that the major barriers to the integration of pharmaceutical care into practice were lack of private counseling areas or inappropriate pharmacy layout $(95.2 \%)$, lack of pharmacist time (83.3\%), organizational obstacles $(82.6 \%)$, and pharmacists' physical separation from patient care areas (82.6\%)

Conclusion: Pharmacy students' attitudes and perceived preparedness can serve as needs assessment tools to guide curricular change and improvement. Student pharmacists at Kuwait University understand and advocate implementation of pharmaceutical care while also recognizing the barriers to its widespread adoption. The education and training provided at Kuwait University Faculty of Pharmacy is designed to develop students to be the change agents who can advance pharmacist-provided direct patient care.
\end{abstract}

"Maram Gamal KATOUE. MSc (Pharmacol). Teaching Assistant, Department of Pharmacology and Therapeutics, Faculty of Pharmacy, Kuwait University. Kuwait (Kuwait). maramk@hsc.edu.kw

Abdelmoneim I. AWAD. PhD. Chair and Associate Professor, Department of Pharmacy Practice, Faculty of Pharmacy, Kuwait University. Kuwait (Kuwait).

amoneim@hsc.edu.kw

Terry L. SCHWINGHAMMER. PharmD, BCPS. Chair and Professor, Department of Clinical Pharmacy, West Virginia University School of Pharmacy, Morgantown, West Virginia, USA. tschwinghammer@hsc.wvu.edu Samuel B. KOMBIAN. PhD. Professor, Department of Pharmacology and Therapeutics, Faculty of Pharmacy, Kuwait University. Kuwait (Kuwait). kombian@hsc.edu.kw
Keywords: Students, Pharmacy; Education, Pharmacy; Curriculum; Attitude of Health Personnel; Professional Role; Kuwait

\section{INTRODUCTION}

There has been a gradual transition in the professional responsibilities of the pharmacist from traditional tasks such as medication compounding and dispensing to providing patient-centered care. The concept of pharmaceutical care has long been espoused as a practice philosophy that encompasses all of the services that the pharmacist responsibly provides to patients to ensure the most effective use of medication therapy to achieve definite outcomes that improve their quality of life. ${ }^{1}$ The primary mission of the pharmacist is to provide pharmaceutical care. ${ }^{2}$ Extensive research and implementation projects proved the benefits of pharmaceutical care on patient care and clinical outcomes. $^{3}$

Pharmacy educators are responsible for preparing student pharmacists to be competent to implement pharmaceutical care in their future practice. ${ }^{2}$ Students must be provided with ample opportunity to develop the clinical knowledge foundation and effective communication skills needed to serve the needs of patients. It is equally important to instill in students positive attitudes and motivation to provide pharmaceutical care. ${ }^{4}$ This combination of knowledge, skills and attitudes is required for widespread acceptance and implementation of the concept of pharmaceutical care.

Very few publications have documented the status of pharmacy education in Kuwait. ${ }^{5,6}$ Faculty of Pharmacy at Kuwait University is the only public pharmacy school in Kuwait. The Faculty was established in 1996 and admitted its first group of students in September 1997. The Bachelor of Pharmacy (B. Pharm) degree program offered by the Faculty is a 10-semester (total 5-year) program with the first two semesters spent in a common year with medical and dental students. In the first year of study, students enroll in pre-professional courses. Students who choose or are assigned to pharmacy according to their grade point average (GPA) of the first year undertake professional courses for four years. The Faculty's current curriculum is designed to foster students' abilities to communicate effectively; solve problems; make rational, independent judgments based upon sound scientific reasoning; and engender a caring attitude in their professional interactions with patients.

The concept of pharmaceutical care is first introduced to students in the second year of the 
curriculum. In the pharmacy practice course, students are provided with a definition of the concept and description of basic pharmaceutical care principles. In the third through fourth years of study, students are taught about the pharmaceutical care aspects related to management of various disease states in the pharmacy practice courses. This is delivered through lectures which are reinforced with both dispensing laboratories and small group discussion on case studies. They also undertake experiential training (clerkships) with a minimum of 130 hours in primary health care centers and community pharmacies. In their final year, the students take an advanced pharmaceutical care course and have more extensive experiential training with a minimum of 390 hours in general and specialized hospitals. The experiential training experience provides the students with the opportunity to practise a range of pharmaceutical care skills. These include interviewing patients, retrieving patient data from medical files, and developing a patient specific pharmaceutical care plan for the identification, resolution and prevention of drug-therapy problems.

The attitude of pharmacy students towards pharmaceutical care has been investigated in other developing countries, ${ }^{7-9}$ but no such studies have been conducted in Kuwait. Assessing pharmacy students' attitudes towards pharmaceutical care and perceptions of their preparedness to perform pharmaceutical care competencies can provide useful information to guide curricular change and improvement. Therefore, the present study was designed to describe the attitudes of pharmacy students towards pharmaceutical care, perceptions of their preparedness to perform pharmaceutical care competencies, their perceived importance of the various pharmaceutical care activities, and their opinions about the potential barriers to the provision of pharmaceutical care in Kuwait.

\section{METHODS}

\section{Study population}

The study population consisted of three different student cohorts from two professional years (fourth and fifth year), each representing a professional class at a different stage of the curriculum. This included fifth-year students (2011-2012) and fourthyear students (2011-2012) who were surveyed in June 2012 at the end of the second semester, and fourth-year students (2012-2013) who were surveyed in December 2012 at the end of the first semester.

\section{Survey design}

A descriptive, cross-sectional survey of pharmacy students was conducted at Faculty of Pharmacy, Kuwait University. Data were collected in June 2012 at the end of the second semester of the academic year 2011-2012 and in December 2012 at the end of the first semester of the academic year 20122013. The questionnaire was developed primarily from survey instruments designed and used in the United States. ${ }^{10-13}$ It was pre-tested for content, design, readability and comprehension on 15 pharmacy students, and modifications were made as necessary. The final version of the questionnaire had five sections. The first section provided information on the socio-demographic characteristics of the respondents, including age, gender, marital status, nationality and educational level. The second section was used to assess the attitudes of students towards pharmaceutical care and consisted of the Standard Pharmaceutical Care Attitude Survey (PCAS). ${ }^{10,11}$ It includes statements about pharmaceutical care for which respondents were asked to indicate their level of agreement on a 5 -point Likert scale ( $1=$ strongly disagree, $5=$ strongly agree). The third section consisted of a reduced version of the Perceptions of Preparedness to Provide Pharmaceutical Care (PREP) survey. ${ }^{12,13}$ It was designed to assess the perceptions of students regarding their ability to perform various pharmaceutical care competencies and to rate that on a 5-point Likert scale (1=poor, $5=$ excellent). Section four was used to reveal the opinions of students about the importance of the various pharmaceutical care activities using a 4-point Likert scale (1=unimportant, 4=very important). In the last section, a 5-point Likert scale (1=strongly disagree, $5=$ strongly agree) was used to measure students' level of agreement with a number of potential barriers contributing to limiting the delivery of pharmaceutical care in practice settings.

\section{Survey administration}

In order to obtain the highest possible response rate, the students were approached after major lectures, and the survey was distributed and conducted in class. The purpose of the study was briefly explained to students, and they were informed that responses would be anonymous. Participants were assured of confidentiality and provided written consent to participate in the study. Ethical approval for the study was obtained from the Joint Committee for the Protection of Human Subjects in Research of the Health Science Centre, Kuwait University and Kuwait Institute for Medical Specialization.

\section{Data analysis}

Data were entered into the SPSS, version 19, and descriptive and comparative analyses were conducted. Responses were presented as percentages, medians and means Likert scale rating and standard deviations (SD). The differences in the scale mean responses of the three cohorts of students to the items assessing their attitudes, perceptions of their preparedness and opinions about pharmaceutical care activities were determined using Kruskal-Wallis test. Statistical significance was accepted at a $p$ value of 0.05 or lower.

\section{RESULTS}

\section{Study population}

A total of 127 students were approached regarding study participation, 126 of whom completed and returned the questionnaire (response rate of $99.2 \%$ ). The mean age of respondents was 21.8 


\begin{tabular}{|c|c|c|}
\hline & Frequency & $\%$ \\
\hline Gender & $\begin{array}{c}16 \\
110\end{array}$ & $\begin{array}{l}12.7 \\
87.3\end{array}$ \\
\hline Marital status & $\begin{array}{l}98 \\
28\end{array}$ & $\begin{array}{l}77.8 \\
22.2\end{array}$ \\
\hline $\begin{array}{r}\text { Kuwaiti } \\
\text { Non-Kuwaiti }\end{array}$ & $\begin{array}{c}107 \\
19\end{array}$ & $\begin{array}{l}84.9 \\
15.1\end{array}$ \\
\hline $\begin{array}{l}\text { Educational level } \\
4^{\text {th }} \text { year students }(2012-2013) \\
4^{\text {th }} \text { year students }(2011-2012) \\
5^{\text {th }} \text { year students }(2011-2012)\end{array}$ & $\begin{array}{l}63 \\
36 \\
27\end{array}$ & $\begin{array}{l}50.0 \\
28.6 \\
21.4\end{array}$ \\
\hline
\end{tabular}

$(S D=1.2)$ years. Half of the total sample $(50 \%)$ were fourth-year students surveyed at the end of the first semester $\left(4^{\text {th }}\right.$ year students, 2012-2013), $28.6 \%$ of the sample were fourth-year students surveyed at the end of the second semester $\left(4^{\text {th }}\right.$ year students, 2011-2012) and $21.4 \%$ were fifth-year students surveyed at the end of the second semester $\left(5^{\text {th }}\right.$ year students, 2011-2012). Table 1 shows the characteristics of respondents.

\section{Attitudes towards pharmaceutical care}

Table 2 shows students' responses to the different items of the PCAS. The respondents agreed/strongly agreed on most of the statements in the survey reflecting favorable attitudes towards pharmaceutical care. They had mean scores rating above the midpoint of 3.0 on the scale for all items of PCAS. The only exception was noted for the item relating to the additional workload needed for the provision of pharmaceutical care with a mean (SD) response of 2.3 (1.2).

\section{Perceptions of preparedness to provide pharmaceutical care}

The students' ratings of their perceived preparedness to perform various pharmaceutical care competencies are presented in Table 3. Generally, students rated their preparedness to provide pharmaceutical care as being "good" to "very good", with overall mean (SD) responses of 3.1 (1.2). The students' highest perceived preparedness was in the psychosocial aspects of pharmaceutical care, 3.3 (1.2), followed by communication, 3.2 (1.2), technical, 3.1 (1.1) and lastly the administrative aspects, 2.7 (1.1). Of all the competencies, students reported the highest levels of perceived preparedness to use data/computers in professional practice, 3.7 (1.0), followed by promotion of public awareness of health, 3.5 (1.2).

\section{Opinions about the importance of the pharmaceutical care activities}

Table 4 reports students' opinions regarding the importance of the different pharmaceutical care activities performed by pharmacists. The students rated most of the activities as being important to very important, with overall mean (SD) responses of 3.6 (0.7). The most important perceived competencies were: pharmacists' ability to obtain accurate information on all the medications currently taken by the patient, $3.7(0.9)$; the ability to explain using words that are easy to be understood by patients; to recommend changes after review or monitoring of drug therapy; and to recommend dose adjustments, $3.7(0.6)$. Students felt that performing limited physical examination and discussing patient case with physician are the least important competencies, 3.4 (0.7).

\section{Opinions about the barriers to the provision of pharmaceutical care}

Students' opinions about the potential barriers to the provision of pharmaceutical care in Kuwait are shown in Table 5 . The students agreed to strongly

\begin{tabular}{|c|c|c|c|c|c|c|c|}
\hline \multirow{2}{*}{ Item } & \multicolumn{5}{|c|}{ Response values $^{a}(\%)$} & \multirow{2}{*}{ Mean (SD) } & \multirow{2}{*}{ Median } \\
\hline & 1 & 2 & 3 & 4 & 5 & & \\
\hline 1. All pharmacists should perform pharmaceutical care. & 1.6 & 8.7 & 7.1 & 32.5 & 50.0 & $4.2(1.0)$ & 4.5 \\
\hline $\begin{array}{l}\text { 2. The primary responsibility of pharmacists in all health } \\
\text { care settings should be to prevent and solve medication- } \\
\text { related problems. }\end{array}$ & 1.6 & 3.2 & 4.0 & 42.1 & 49.2 & $4.3(0.8)$ & 4.0 \\
\hline $\begin{array}{l}\text { 3. Pharmacists' primary responsibility should be to practise } \\
\text { pharmaceutical care. }\end{array}$ & 1.6 & 3.2 & 7.1 & 41.3 & 46.8 & $4.3(0.9)$ & 4.0 \\
\hline $\begin{array}{l}\text { 4. Pharmacy students can perform pharmaceutical care } \\
\text { during their experiential training (placements). }\end{array}$ & 4.8 & 14.3 & 22.2 & 36.5 & 22.2 & $3.6(1.1)$ & 4.0 \\
\hline 5. I think the practice of pharmaceutical care is valuable. ${ }^{b}$ & 2.4 & 4.8 & 11.1 & 31.0 & 50.0 & $4.3(1.1)$ & 5.0 \\
\hline $\begin{array}{l}\text { 6. Providing pharmaceutical care takes too much time and } \\
\text { effort. }\end{array}$ & 0.8 & 11.9 & 17.5 & 42.1 & 27.8 & $3.8(1.0)$ & 4.0 \\
\hline $\begin{array}{l}\text { 7. I would like to perform pharmaceutical care as a } \\
\text { pharmacist practitioner. }\end{array}$ & 3.2 & 3.2 & 7.9 & 35.7 & 50.0 & $4.3(1.0)$ & 4.5 \\
\hline $\begin{array}{l}\text { 8. } \begin{array}{l}\text { Providing pharmaceutical care is professionally } \\
\text { rewarding. }\end{array} \\
\end{array}$ & 2.4 & 5.6 & 11.9 & 26.2 & 54.0 & $4.2(1.0)$ & 5.0 \\
\hline $\begin{array}{l}\text { 9. I feel that pharmaceutical care is the right direction for the } \\
\text { profession to be headed. }{ }^{b}\end{array}$ & 2.4 & 0.8 & 8.7 & 25.4 & 60.3 & $4.6(1.1)$ & 5.0 \\
\hline $\begin{array}{l}\text { 10. I feel that the pharmaceutical care movement will benefit } \\
\text { pharmacists. }\end{array}$ & 1.6 & 0.8 & 4.8 & 34.1 & 58.7 & $4.5(0.8)$ & 5.0 \\
\hline $\begin{array}{l}\text { 11. I feel that the pharmaceutical care movement will } \\
\text { improve patients' health. }\end{array}$ & 1.6 & 1.6 & 0.8 & 24.6 & 71.4 & $4.6(0.7)$ & 5.0 \\
\hline $\begin{array}{l}\text { 12. I feel that practicing pharmaceutical care would benefit } \\
\text { my professional career as a pharmacy practitioner. }\end{array}$ & 1.6 & 0.8 & 6.3 & 31.7 & 59.5 & $4.5(0.8)$ & 5.0 \\
\hline $\begin{array}{l}\text { 13. Providing pharmaceutical care is not worth the } \\
\text { additional workload that it places on the pharmacist. }{ }^{b}\end{array}$ & 26.2 & 45.2 & 12.7 & 12.7 & 2.4 & $2.3(1.2)$ & 2.0 \\
\hline
\end{tabular}




\begin{tabular}{|c|c|c|c|c|c|c|c|}
\hline \multirow{2}{*}{ Competency Area } & \multicolumn{5}{|c|}{ Response values $^{\text {a }}(\%)$} & \multirow{2}{*}{ Mean(SD) } & \multirow{2}{*}{ Median } \\
\hline & 1 & 2 & 3 & 4 & 5 & & \\
\hline \multicolumn{8}{|l|}{ Technical aspects } \\
\hline 1. Recommend appropriate drug therapy. & 10.3 & 27.0 & 38.1 & 15.9 & 8.7 & $2.9(1.1)$ & 3.0 \\
\hline $\begin{array}{l}\text { 2. Evaluate patient pharmacotherapeutic regimens to prevent or resolve } \\
\text { medication-related problems. }\end{array}$ & 5.6 & 29.4 & 34.9 & 20.6 & 8.7 & $3.0(1.2)$ & 3.0 \\
\hline 3. Determine drug delivery system. ${ }^{b}$ & 7.9 & 20.6 & 33.3 & 27.8 & 9.5 & $3.2(1.2)$ & 3.0 \\
\hline 4. Recommend medication doses /dose schedules. ${ }^{b}$ & 7.9 & 28.6 & 33.3 & 21.4 & 7.9 & $3.0(1.2)$ & 3.0 \\
\hline $\begin{array}{l}\text { 5. Identify/collect information to prevent or resolve a drug therapy } \\
\text { problem. }\end{array}$ & 3.2 & 25.4 & 28.6 & 32.5 & 10.3 & $3.2(1.0)$ & 3.0 \\
\hline 6. Evaluate laboratory tests for a specific patient. & 7.1 & 18.3 & 34.9 & 29.4 & 10.3 & $3.2(1.1)$ & 3.0 \\
\hline 7. Calculate/evaluate pharmacokinetic properties. ${ }^{b}$ & 8.7 & 36.5 & 33.3 & 17.5 & 3.2 & $2.8(1.1)$ & 3.0 \\
\hline 8. Evaluate information from patient's history and assessment. & 0.8 & 20.6 & 32.5 & 33.3 & 12.7 & $3.4(1.0)$ & 3.0 \\
\hline 9. Make reasonable conclusions when data is incomplete. & 7.1 & 35.7 & 37.3 & 15.1 & 4.8 & $2.8(1.0)$ & 3.0 \\
\hline 10. Provide counseling to patients. & 7.1 & 19.8 & 30.2 & 29.4 & 13.5 & $3.2(1.1)$ & 3.0 \\
\hline 11. Recommend methods to seek patient compliance. ${ }^{b}$ & 3.2 & 20.6 & 31.7 & 31.0 & 12.7 & $3.3(1.2)$ & 3.0 \\
\hline Overall mean & & & & & & $3.1(1.1)$ & \\
\hline \multicolumn{8}{|l|}{ Psychosocial aspects } \\
\hline $\begin{array}{l}\text { 14. Identify the appropriate information to decide a course of action for } \\
\text { a problem. }\end{array}$ & 5.6 & 29.4 & 33.3 & 24.6 & 6.3 & $3.0(1.2)$ & 3.0 \\
\hline 15. Contribute opinions/insights to health care team. ${ }^{b}$ & 5.6 & 33.3 & 28.6 & 20.6 & 11.1 & $3.0(1.2)$ & 3.0 \\
\hline 16. Promote public awareness of health. ${ }^{b}$ & 5.6 & 13.5 & 33.3 & 24.6 & 22.2 & $3.5(1.2)$ & 3.0 \\
\hline 17. Data/computer use in professional practice. & 3.2 & 7.9 & 27.0 & 35.7 & 26.2 & $3.7(1.0)$ & 4.0 \\
\hline Overall mean & & & & & & $3.3(1.2)$ & \\
\hline \multicolumn{8}{|l|}{ Communication aspects } \\
\hline 18. Communicate medical records information to health professionals. ${ }^{b}$ & 6.3 & 27.0 & 29.4 & 22.2 & 14.3 & $3.2(1.3)$ & 3.0 \\
\hline 19. Communicate medical records information to patient. & 5.6 & 23.0 & 35.7 & 19.0 & 16.7 & $3.2(1.1)$ & 3.0 \\
\hline $\begin{array}{l}\text { 20. Identify/collect information to respond to health professional drug } \\
\text { information request. }\end{array}$ & 6.3 & 24.6 & 31.0 & 26.2 & 11.1 & $3.2(1.2)$ & 3.0 \\
\hline 21. Respond to information request from a patient. ${ }^{b}$ & 6.3 & 18.3 & 37.3 & 31.0 & 6.3 & $3.2(1.1)$ & 3.0 \\
\hline Overall mean & & & & & & $3.2(1.2)$ & \\
\hline \multicolumn{8}{|l|}{ Administrative/Management aspects } \\
\hline 24. Manage fiscal and human resources. ${ }^{b}$ & 13.5 & 33.3 & 28.6 & 18.3 & 5.6 & $2.7(1.2)$ & 3.0 \\
\hline 25. Develop/implement drug formulary service. & 14.3 & 23.0 & 40.5 & 16.7 & 5.6 & $2.8(1.1)$ & 3.0 \\
\hline Overall mean & & & & & & $2.7(1.1)$ & \\
\hline \multicolumn{6}{|c|}{ Overall scale mean (for all competency items) } & $3.1(1.2)$ & \\
\hline
\end{tabular}

agreed that the most formidable barriers to the integration of pharmaceutical care services into practice were: lack of private counseling areas or inappropriate pharmacy layout $(95.2 \%)$, lack of pharmacist time $(83.3 \%)$, organizational obstacles such as the absence of health care policy to support the role of pharmacist in patient care $(82.6 \%)$, pharmacists' physical separation from patient care area $(82.6 \%)$, and lack of physicians' trust in the pharmacists' abilities, (77.7\%).

\section{Comparative analysis of students' responses between the three student cohorts}

Students' attitudes towards pharmaceutical care, perceptions of their preparedness to perform pharmaceutical care competencies and perceived importance of the various pharmaceutical care activities were compared by educational level (Table 6). There was no significant difference between the three cohorts of students in their attitudes towards pharmaceutical care $(p>0.05)$, with the three groups showing positive attitudes. On the other hand, there was a significant difference in students' perceptions of their preparedness to provide pharmaceutical care competencies between the three cohorts $(p<0.01)$. Fourth-year students surveyed in the first semester felt that their preparedness was average to good, 2.7 (1.1). The average score increased to 3.3 (1.2) for fourth-year students surveyed in the second semester. The final-year students rated their preparedness as being good to very good, $3.6(0.9)$. Similarly, there was a significant difference between the three cohorts in their opinions about the importance of the pharmaceutical care activities $(p<0.01)$.

\section{DISCUSSION}

Pharmacy curricula must provide education and training that imparts the necessary clinical knowledge, skills, and positive attitudes to practise pharmaceutical care. To the best of our knowledge, this is the first study to investigate pharmacy students' attitudes towards pharmaceutical care and perceptions of their preparedness to provide pharmaceutical care in Kuwait. These findings provide useful information to guide curricular change that enhances the training of pharmacy graduates to better serve the needs of patients and the profession.

In this study, the student cohorts were selected because the students in each group were 


\begin{tabular}{|c|c|c|c|c|c|c|}
\hline \multirow{2}{*}{ The pharmacists ability to: } & \multicolumn{4}{|c|}{ Response values $^{\mathrm{a}}(\%)$} & \multirow{2}{*}{ Mean(SD) } & \multirow{2}{*}{ Median } \\
\hline & 1 & 2 & 3 & 4 & & \\
\hline 1. Identify expected therapeutic outcomes of drug therapy. & 3.2 & 4.0 & 32.5 & 60.3 & $3.5(0.7)$ & 4.0 \\
\hline 2. Select parameters of patient care to monitor drug therapy. & 2.4 & 5.6 & 27.0 & 65.1 & $3.6(0.7)$ & 4.0 \\
\hline 3. Provide follow-up services for drug therapy, e.g. monitoring response to therapy. & 3.2 & 8.7 & 26.2 & 61.9 & $3.5(0.8)$ & 4.0 \\
\hline 4. Perform limited physical exams. & 1.6 & 8.7 & 39.7 & 50.0 & $3.4(0.7)$ & 3.5 \\
\hline 5. Access to clinical laboratory tests records. & 1.6 & 7.9 & 35.7 & 54.8 & $3.4(0.7)$ & 4.0 \\
\hline 6. Discuss patient case with physician. & 1.6 & 8.7 & 33.3 & 56.3 & $3.4(0.7)$ & 4.0 \\
\hline 7. Interview patients. & 7.1 & 31.7 & 60.3 & 0.8 & $3.6(0.8)$ & 4.0 \\
\hline 8. Access to patient medical records. ${ }^{b}$ & 1.6 & 4.8 & 34.1 & 58.7 & $3.6(0.8)$ & 4.0 \\
\hline 9. Recommend dose adjustments. & 1.6 & 2.4 & 24.6 & 71.4 & $3.7(0.6)$ & 4.0 \\
\hline 10. Provide complete drug therapy information. & 0.8 & 6.3 & 27.0 & 65.9 & $3.6(0.7)$ & 4.0 \\
\hline 11. Have accurate information on all the medications taken by patient. ${ }^{b}$ & 0.8 & 4.0 & 24.6 & 69.0 & $3.7(0.9)$ & 4.0 \\
\hline 12. Have accurate updated information on OTCs. & 1.6 & 4.8 & 28.6 & 65.1 & $3.6(0.7)$ & 4.0 \\
\hline 13. Assess patients' needs for review of drug therapy. & 2.4 & 4.8 & 31.7 & 61.1 & $3.5(0.7)$ & 4.0 \\
\hline 14. Assess patients' needs for drug therapy monitoring. & 3.2 & 4.8 & 28.6 & 63.5 & $3.5(0.7)$ & 4.0 \\
\hline 15. Assess patients' needs for advice on lifestyle modifications. & 1.6 & 4.8 & 36.5 & 57.1 & $3.5(0.7)$ & 4.0 \\
\hline 16. Undertake review of drug therapy as part of regular ward rounds. & 2.4 & 8.7 & 31.0 & 57.9 & $3.4(0.8)$ & 4.0 \\
\hline 17. Provide counseling on medicines use and side effects. & 0.8 & 3.2 & 28.6 & 67.5 & $3.6(0.6)$ & 4.0 \\
\hline 18. Provide counseling on lifestyle modifications. & 1.6 & 5.6 & 31.0 & 61.9 & $3.5(0.7)$ & 4.0 \\
\hline 19. Monitor compliance with medicines. & 2.4 & 3.2 & 29.4 & 65.1 & $3.6(0.7)$ & 4.0 \\
\hline 20. Monitor side effects of medicines. & 2.4 & 2.4 & 32.5 & 62.7 & $3.6(0.7)$ & 4.0 \\
\hline 21. Recommend changes after review or monitoring of drug therapy. & 1.6 & 3.2 & 22.2 & 73.0 & $3.7(0.6)$ & 4.0 \\
\hline 22. Communicate with other members of health care team. ${ }^{b}$ & 1.6 & 8.7 & 33.3 & 55.6 & $3.5(0.9)$ & 4.0 \\
\hline 23. Communicate with patients effectively. & 1.6 & 4.0 & 28.6 & 65.9 & $3.6(0.7)$ & 4.0 \\
\hline 24. Detect and respond to nonverbal cues. & 2.4 & 7.9 & 33.3 & 56.3 & $3.4(0.7)$ & 4.0 \\
\hline 25. Listen to patients effectively. & 1.6 & 3.2 & 24.6 & 70.6 & $3.6(0.6)$ & 4.0 \\
\hline 26. Explain by words that are easy to be understood by patients. & 1.6 & 1.6 & 19.8 & 77.0 & $3.7(0.6)$ & 4.0 \\
\hline Overall scale mean & & & & & $3.6(0.7)$ & \\
\hline
\end{tabular}

introduced to the concept of pharmaceutical care and they were exposed to clerkship experience. The different groups were targeted to examine potential differences in attitudes and perceptions towards pharmaceutical care based on students' stage in the curriculum and duration of experiential training.

The results show that students expressed overall positive attitudes towards pharmaceutical care with no significant difference between the three cohorts. The students had high mean scores rating for all items of PCAS except for the item relating to the additional workload needed for the provision of pharmaceutical care. This item is negatively worded in PCAS to minimize mechanical responses. Lower mean responses to this item reflect a favorable disposition towards pharmaceutical care. This suggests that the current pharmacy curriculum encourages the development of pharmacist practitioners who are motivated to incorporate the concept of pharmaceutical care into their future practice. This finding is consistent with similar studies conducted in the United States ${ }^{11}$, Saudi Arabia $^{7}$, Nigeria $^{8}$ and Pakistan ${ }^{9}$, in which pharmacy students were well-disposed towards the concept. Pharmacy education must provide students with adequate knowledge, skills, and a set of values and attitudes that support the assumption of enhanced responsibilities for performing pharmaceutical care. $^{14}$

In the present study, the students felt prepared to implement the different aspects of pharmaceutical care, albeit to varying degrees. They perceived their level of preparedness to perform pharmaceutical care competencies to be highest in the psychosocial

\begin{tabular}{|c|c|}
\hline Barrier to Pharmaceutical Care & $\begin{array}{l}\text { Percentage of student pharmacists } \\
\text { who agreed/strongly agreed }(\%)\end{array}$ \\
\hline 1. Lack of private counseling area, space or inappropriate pharmacy layout. & 95.2 \\
\hline 2. Lack of time to provide pharmaceutical care. & 83.3 \\
\hline $\begin{array}{l}\text { 3. Organizational obstacles: e.g. lack of support from administration, absence of health care } \\
\text { policy for pharmacists' patient care role. }\end{array}$ & 82.6 \\
\hline 4. Pharmacists being physically distinct from patient care area. & 82.6 \\
\hline 5. Lack of physicians' trust in the pharmacists' abilities. & 77.7 \\
\hline 6. Lack of communication/coordination with physicians. & 74.6 \\
\hline 7. Physicians will not accept pharmacists' new role. & 71.5 \\
\hline 8. Inadequate teamwork of the health care members. & 68.2 \\
\hline 9. Inadequate pharmaceutical care training or continuing professional education of practitioners. & 68.2 \\
\hline 10. Inadequate staffing, e.g. deficient number of pharmacy technicians. & 65.1 \\
\hline 11. Deficient clinical knowledge of pharmacists. & 59.5 \\
\hline 12. Lack of patient interest. & 57.9 \\
\hline 13. Negative attitudes of pharmacists towards pharmaceutical care. & 57.2 \\
\hline 15. Inadequate computer system/software and/or inadequate computer training of personnel. & 53.2 \\
\hline 16. Lack of financial compensation for the activities that are related to patient care. & 50.7 \\
\hline
\end{tabular}




\begin{tabular}{|l|c|c|c|}
\hline \multicolumn{4}{|c|}{ Table 6. Comparative statistics of students' responses between the three student cohorts. } \\
\hline & $\begin{array}{c}\text { Attitude Scale } \\
\text { Mean(SD) }\end{array}$ & $\begin{array}{c}\text { Preparedness Scale } \\
\text { Mean(SD) }\end{array}$ & $\begin{array}{c}\text { Opinions Scale } \\
\text { Mean(SD) }\end{array}$ \\
\hline $4^{\text {th }}$ year students (2012-2013) & $4.1(1.1)$ & $2.7(1.1)$ & $3.5(0.8)$ \\
\hline $4^{\text {th }}$ year students (2011-2012) & $4.2(1.1)$ & $3.3(1.2)$ & $3.6(0.7)$ \\
\hline $5^{\text {th }}$ year students (2011-2012) & $4.1(1.2)$ & $3.6(0.9)$ & $3.7(0.5)$ \\
\hline$p$ value & $>0.05$ & $<0.01$ & $<0.01$ \\
\hline
\end{tabular}

aspects, followed by communication, technical, and lastly the administrative aspects of care. These results are comparable to two similar studies conducted in the United States. ${ }^{12,13}$ This is not surprising given that students have an earlier exposure to courses covering these aspects of care, as well as an everyday experience with communications. On the other hand, these results highlight the need to evaluate the courses covering the administrative aspects of pharmaceutical care within the current curriculum to improve students' preparedness in these aspects. It was quite promising to find that respondents rated the highest level of readiness to use technology in professional practice and to promote public awareness of health. This could be due to the fact that the Faculty of Pharmacy has always employed cutting-edge technology to assist students in acquiring the skills to excel in professional practice. ${ }^{15}$ Furthermore, the current curriculum also prepares students to become heath educators. In a country like Kuwait, where the burden of chronic diseases such as obesity $^{16}$ and diabetes ${ }^{17}$ is increasing among the population, pharmacists can have major contributions to increasing public awareness about these emerging epidemics.

The current findings also show a stepwise improvement in students' perceived preparedness as they progress through the curriculum, with the most senior students having the highest selfassessed level of competence. To the extent that these perceptions reflect students' actual competencies, this indicates that the curriculum was successful in teaching students pharmaceutical care skills. The students also appreciated the importance of the various pharmaceutical care competencies with a similar upward trend in their opinions as they advance through the curriculum. This could reflect an increasing level of professional maturation as the students continued their coursework and experiential training. Notably, students ranked pharmacists' ability to perform limited physical examination for patients as the least important competency. This may mirror the traditional thinking that only physicians are trained to perform these activities. However, it has been reported that community pharmacists in Kuwait routinely provide patient monitoring services such as weight and blood pressure measurements. ${ }^{18}$

In order to expand the provision of pharmaceutical care services in practice settings, identifying the barriers that limit its implementation should be a priority. Because students undertake experiential training at different pharmacy environments, they can observe and report these barriers. The major barriers reported by the students concur with the findings of a previous study conducted among hospital pharmacists in Kuwait. ${ }^{19}$ The reported barriers are not unique to the health care system in
Kuwait. In fact, many of these barriers were identified as obstacles to the implementation of pharmaceutical care in studies conducted in developed countries. ${ }^{20,21}$ This underscores the need for restructuring pharmacy layout to overcome the lack of private counseling areas, the principal barrier identified in this study. Lack of pharmacist time can be partly overcome by better delineation between the roles of the pharmacist and the pharmacy technician. Establishing national policy/legislations to define the emerging professional roles of the pharmacist is urgently needed. Moreover, opportunities should be created for Kuwait pharmacists to work closely with physicians in the settings of hospital wards or physician office practice. This would improve physicians' trust in the pharmacists, thereby promoting the physicianpharmacist partnership in patient care.

A major curricular limitation is that pharmaceutical care services are not generally provided at the pharmacy sites used for students experiential training. As a result, students have limited opportunity to observe the actual application of pharmaceutical care principles to practice. Indeed, many students recognize a gap between what is being taught at the Faculty and what is actually practised at the pharmacy training sites. To enhance students' preparedness, it is essential to provide practice sites for their experiential training where they can participate in the integration of pharmaceutical care activities into pharmacy practice. In view of the limited availability of these ideal sites, simulation could be used as adjunct to experiential training to enable students to acquire the necessary practice experience. Simulation is a valuable teaching technique that has been integrated in pharmacy education to prepare students for pharmacy practice. ${ }^{22}$ Simulation can be integrated in students learning as early as possible in the curriculum, perhaps starting from the second professional year to train students on essential pharmacy practice skills such as communication. Simulation has been used successfully in pharmacy education in areas such as therapeutics, communication, physical assessment, patient safety and interprofessional health care team skills. ${ }^{22}$ Therefore, when students' understanding about pharmaceutical care starts to take shape in the third year, simulated case scenarios using simulated patients or high-fidelity human patient simulation can be used to illustrate to them the requisite pharmaceutical care competencies. The Faculty is currently establishing a clinical skills environment (virtual ward environment) and a mock pharmacy to provide students an opportunity to apply previously acquired knowledge and skills to practise pharmaceutical care in realistic clinical settings. This would enhance students' preparation for practice and could partly overcome the absence of the ideal sites for their experiential training. 
Furthermore, fostering interprofessional education (IPE) can enhance students' preparation for pharmaceutical care practice. IPE promotes the development of sustained working relationships among health care professionals. ${ }^{23}$ A deliberate educational strategy should be designed to offer undergraduate pharmacy and medical students interprofessional learning opportunities starting from the earliest stages of their degrees. This will foster collaborative attitudes among them as future health care professionals, with the ultimate goal of improving the quality of patient care. Pharmacy and medical students in their second and third years of studies should be offered IPE courses with focus on communication and interpersonal skills, analyzing ethical issues, and developing their understanding of the other professions. This will give them the opportunity to recognize and appreciate their similarities, as well as their unique roles, with the goal of enhancing future collaborative work. Plans are currently underway to jointly develop and run multidisciplinary interprofessional courses with the Faculties of Medicine and Dentistry. However, care should be given to develop collaborative learning models, in which students are not passive recipients of knowledge through didactic teaching. Instead, health sciences students, including pharmacy and medical students should be engaged in interactive shared learning that would help them appreciate the value and contributions of each profession to patient and health outcomes. ${ }^{23}$ This would enhance collaborative practices and the multidisciplinary approach to patient care.

The university and the health care authorities (Ministry of Health) should develop strategies to bridge the obvious gaps between what is being taught to students about pharmaceutical care and the actual pharmacy practice in Kuwait, which currently lacks pharmaceutical care services. Suggested solutions include establishing National Standards of Practice or competencies for the profession to ensure the excellence of pharmacy education provided to future pharmacy practitioners. This would also be essential for the continuous quality improvement of the curriculum. These standards would guide Faculty of Pharmacy in curricular assessment, evaluation and revision to address the education and practice needs of the profession. The Faculty should also consider offering specific training to the preceptors who supervise students during their experiential training to help them demonstrate and teach pharmaceutical care competencies to students. These educational interventions should encourage the preceptors to change the current pharmacy training sites to ones in which pharmaceutical care services are actively provided to patients. In addition, more emphasis should be placed on pharmacists' clinical training to improve the clinical pharmacy services in Kuwait. The University has recently approved a Pharm D degree program that will provide a post-bachelor clinical training during which pharmacists develop the requisite clinical skills to provide standard pharmaceutical care.

A potential limitation of this study is the student selfreporting of attitudes and perceptions of preparedness to provide pharmaceutical care. Selfreported competence may not necessarily reflect students' actual competence. Therefore, these findings should be interpreted cautiously in conjunction with the results of objective assessment of students' competencies by faculty members and preceptors. Another potential limitation is that students' responses may be influenced by what is perceived to be the "right" answer. Respondents may be biased with an inclination to provide socially desirable responses.

\section{CONCLUSIONS}

Student pharmacists at Kuwait University have positive attitudes towards pharmaceutical care. The education and training provided at Kuwait University Faculty of Pharmacy encourages the development of pharmacists who are motivated to incorporate the concept of pharmaceutical care into their future practice and seems to be successful in teaching students the necessary pharmaceutical care skills. This prepares students to be the change agents needed to enhance the quality of direct patient care provided by pharmacists.

\section{ACKNOWLEDGEMENTS}

We would like to thank all the student pharmacists who participated in the study.

\section{CONFLICT OF INTEREST}

None declared.

\section{EDUCACIÓN EN ATENCIÓN FARMACÉUTICA EN KUWAIT: PERSPECTIVAS DE LOS ESTUDIANTES DE FARMACIA}

\section{RESUMEN}

Antecedentes: La atención farmacéutica se define como la provisión responsable de un tratamiento farmacológico para alcanzar resultados definidos que mejoren la calidad de vida de los pacientes. La formación en farmacia debería equipar a los estudiantes con el conocimiento, habilidades y actitudes que necesitan para ejercer la atención farmacéutica de modo competente.

Objetivo: Investigar las actitudes de los estudiantes de farmacia hacia la atención farmacéutica, las percepciones de su preparación para ejercer competencias de atención farmacéutica, las opiniones sobre la importancia de las varias actividades de la atención farmacéutica, y las barreras para su implementación en Kuwait.

Métodos: Se realizó un estudio descriptivo transversal a estudiantes de farmacia $(n=126)$ en la Facultad de Farmacia de la Universidad de Kuwait. Se recogieron datos a través de un cuestionario auto-administrado previamente probado. Se calculó la estadística descriptiva que incluía porcentajes, medianas y medias (DE) de las puntuaciones de las escalas Likert y se compararon utilizando SPSS versión 19. La significación estadística se aceptó a un valor de $\mathrm{p}$ de 0,05 o menor.

Resultados: La tasa de respuesta fue del 99,2\%. Los estudiantes de farmacia expresaron actitudes generales positivas hacia la atención farmacéutica. Se sentían preparados para implantar los varios aspectos de la atención farmacéutica, con menos preparación en los aspectos administrativos y de gestión. Las competencias percibidas de atención farmacéutica crecían a medida que 
los estudiantes progresaban en su currículo. Los estudiantes también apreciaban la importancia de los varios componentes de las varias competencias de la atención farmacéutica. Estaban de acuerdo/Muy de acuerdo con que las principales barreras para la integración de la atención farmacéutica en la práctica eran la falta de áreas privadas de consulta o el inadecuado aspecto físico de las farmacias $(95,2 \%)$, falta de tiempo del farmacéutico $(83,3 \%)$, obstáculos organizativos $(82,6 \%)$ y la separación sísica del farmacéutico de las áreas de atención al paciente $(82,6 \%)$.

Conclusión: Las actitudes de los estudiantes de farmacia y su preparación percibida pueden servir como instrumentos de evaluación necesaria para guiar el cambio y la mejora curriculares. Los estudiantes de farmacia de la Universidad de en Kuwait entienden y apoyan la implantación de la atención farmacéutica mientras que reconocen las barreras para su adopción generalizada. La educación y formación proporcionadas en la Facultad de Farmacia de la Universidad de Kuwait están diseñadas para desarrollar a los estudiantes para que sean agentes de cambio que puedan avanzar los cuidaos al pacientes realizados por farmacéuticos.

Palabras clave: Estudiantes de Farmacia; Educación en Farmacia; Currículo; Actitud del Personal de Salud; Rol Profesional; Kuwait

\section{References}

1. Hepler CD. The future of pharmacy: pharmaceutical care. Am Pharm. 1990;NS30(10):23-29.

2. American Society of Hospital Pharmacists. ASHP statement on Pharmaceutical care. Am J Hosp Pharm. 1993;50:17201723.

3. Berenguer B, La Casa C, de la Matta MJ, Martin-Calero MJ. Pharmaceutical care: past, present and future. Curr Pharm Des. 2004;10(31):3931-3946.

4. Chisholm MA, Wade WE. Factors influencing students' attitudes toward pharmaceutical care. Am J Health Syst Pharm. 1999;56(22):2330-2335.

5. Al-Wazaify M, Matowe L, Albsoul-Younes A, Al-Omran OA. Pharmacy education in Jordan, Saudi Arabia, and Kuwait. Am J Pharm Educ. 2006;70(1):18.

6. Kheir N, Zaidan M, Younes H, El Hajj M, Wilbur K, Jewesson PJ. Pharmacy education and practice in 13 Middle Eastern countries. Am J Pharm Educ. 2008;72(6):133.

7. Al-Arifi MN. Pharmacy students' attitudes toward pharmaceutical care in Riyadh region Saudi Arabia. Pharm World Sci. 2009;31(6):677-681. doi: 10.1007/s11096-009-9331-y

8. Udeogaranya PO, Ukwe CV, Ekwunife OI. Assessment of attitudes of university of Nigeria pharmacy students toward pharmaceutical care. Pharm Pract (Granada). 2009;7(3):145-149.

9. Rahim N, Nesar S. Pharmacy undergraduate students' attitude toward pharmaceutical care in Pakistan. Int J Pharm Pharm Sci. 2012;4(4):113-116.

10. Chisholm MA, Martin BC. Development of an instrument to measure student attitudes concerning pharmaceutical care. Am J Pharm Educ. 1997;61(4):374-379.

11. Martin BC, Chisholm MA. Cross-validation of an instrument measuring students attitudes toward pharmaceutical care. Am J Pharm Educ. 1999;63(1):46-51.

12. Ried LD, Brazeau GA, Kimberlin C, Meldrum M, McKenzie M. Students' perceptions of their preparation to provide pharmaceutical care. Am J Pharm Educ. 2002;66(4):347-356.

13. Scott DM, Friesner DL, Miller DR. Pharmacy students' perceptions of their preparedness to provide pharmaceutical care. Am J Pharm Educ. 2010;74(1):8.

14. Adamick BA. Teaching pharmaceutical care: Removing the fences. Am J Pharm Educ. 1992;56:434-441.

15. Matowe L. Use of personal digital assistants for instant access to drug information Med Princ Pract. 2004;13(5):290291.

16. Al Rashdan I, Al Nesef Y. Prevalence of overweight, obesity, and metabolic syndrome among adult Kuwaitis: results from community-based national survey. Angiology. 2010;61(1):42-48. doi: 10.1177/0003319709333226

17. Moussa MA, Alsaeid M, Abdella N, Refai TM, Al-Sheikh N, Gomez JE. Prevalence of type 2 diabetes mellitus among Kuwaiti children and adolescents. Med Princ Pract. 2008;17(4):270-275. doi: 10.1159/000129604

18. Katoue MG, Awad Al, Kombian SB. Role of community pharmacists in the prevention and management of the metabolic syndrome in Kuwait. Int J Clin Pharm. 2013;35(1):57-64. doi: 10.1007/s11096-012-9705-4

19. Awad A, Al-Ebrahim S, Abahussain E. Pharmaceutical care services in hospitals of Kuwait. J Pharm Pharm Sci. 2006;9(2):149-157.

20. May JR. Barriers to pharmaceutical care in the acute care setting. Am J Hosp Pharm. 1993;50(8):1608-1611.

21. Perraudin C, Brion F, Bourdon O, Pelletier-Fleury N. The future of pharmaceutical care in France: a survey of final-year pharmacy students' opinions. BMC Clin Pharmacol. 2011;11:6. doi: 10.1186/1472-6904-11-6

22. Kane-Gill SL, Smithburger PL. Transitioning Knowledge Gained From Simulation to Pharmacy Practice. Am J Pharm Educ. 2011;75(10):210. doi: 10.5688/ajpe7510210

23. Gallagher RM, Gallagher HC. Improving the working relationship between doctors and pharmacists: is inter-professional education the answer? Adv Health Sci Educ Theory Pract. 2012;17(2):247-257. doi: 10.1007/s10459-010-9260-5 